Quim. Nova, Vol. 36, No. 6, 808-814, 2013

\title{
CAT'S CLAW OXINDOLE ALKALOID ISOMERIZATION INDUCED BY COMMON EXTRACTION METHODS
}

\author{
Samuel Kaiser*, Simone Gasparin Verza, Renata Cougo Moraes, Pedro Ernesto de Resende, Cabral Pavei e George \\ González Ortega
}

Faculdade de Farmácia, Universidade Federal do Rio Grande do Sul, 90610-000 Porto Alegre - RS, Brasil

Fabiano Barreto

Laboratório Nacional Agropecuário, 91780-580 Porto Alegre - RS, Brasil

Recebido em 31/8/12; aceito em 24/1/13; publicado na web em 14/5/13

\begin{abstract}
Cat's claw oxindole alkaloids are prone to isomerization in aqueous solution. However, studies on their behavior in extraction processes are scarce. This paper addressed the issue by considering five commonly used extraction processes. Unlike dynamic maceration (DM) and ultrasound-assisted extraction, substantial isomerization was induced by static maceration, turbo-extraction and reflux extraction. After heating under reflux in DM, the kinetic order of isomerization was established and equations were fitted successfully using a four-parameter Weibull model $\left(\mathrm{R}^{2}>0.999\right)$. Different isomerization rates and equilibrium constants were verified, revealing a possible matrix effect on alkaloid isomerization.
\end{abstract}

Keywords: Cat's claw; isomerization of oxindole alkaloids; extraction methods.

\section{INTRODUCTION}

Uncaria tomentosa (Willd.) DC. (Rubiaceae), popularly known as cat's claw or "Uña de Gato", is a South American rainforest climber vine often quoted in folk medicine reports. ${ }^{1,2}$ Immunostimulant, antiviral, and antiproliferative activities have been ascribed to polyphenols, quinovic acid glycosides and, above all, to tetracyclic (TOA) and pentacyclic oxindole alkaloids (POA) isolated from its bark (Figure 1) ${ }^{1,3,4-7}$ In addition, cat's claw oxindole alkaloids are currently used as quality control substances in the US Pharmacopeia. ${ }^{8}$ Nonetheless, both POA and TOA are prone to isomerization, with reaction rates depending on $\mathrm{pH}$, temperature and solvent polarity. ${ }^{9,10}$ The isomerization pathway previously postulated involves a retro-Mannich reaction with an open-ring zwitterionic intermediate. Regarding POA, the interconversion is determined by the configuration of the $\mathrm{D} / \mathrm{E}$ ring junction that can be trans or cis. Thus, the trans configuration leads to the formation of a pair of interconvertible alkaloids (mitraphylline (1) and isomitraphylline (2)), while the cis configuration determines four isomeric forms (speciophylline (3), uncarine $\mathrm{F}(\mathbf{4})$, pteropodine (5) and isopteropodine (6)). ${ }^{9}$ For TOA, two different pairs of interconvertible alkaloids can arise either from the vinyl group attached at C-19 (rhyncophylline (7) and isorhyncophylline (8)) or from the ethyl group (corynoxeine (9) and isocorynoxeine (10)). ${ }^{10}$ Although both POA and TOA are stereoisomers, they present different physicochemical properties because they are diastereoisomers. ${ }^{11}$

The isomerization of cat's claw alkaloids can either modify genuine biological activities or promote new ones, as suggested by results from the antiproliferative activity assay of POA after hot extraction. ${ }^{4,12}$ In addition, POA can manifest different antiproliferative activities when evaluated singly. In this sense, pteropodine (5), uncarine F (4), and, to a lesser extent, isopteropodine (6) and isomitraphylline (2), inhibited leukaemic cell proliferation, whereas mitraphylline (1) was ineffective. ${ }^{3}$ Furthermore, speciophylline (3) showed weak cytotoxic activity against malignant melanoma, as well as against epidermoid, ductal and ovarian carcinoma, whereas isopteropodine (6), mitraphylline (1) and isomitraphylline (2) were

*e-mail: samokaiser@yahoo.com.br ineffectives. ${ }^{13}$ Likewise, antiproliferative activity against human glioma, neuroblastoma, Ewing's sarcoma and breast cancer cell lines, previously ascribed to mitraphylline (1), ${ }^{14,15}$ might depend on experimental conditions, since it easily undergoes isomerization to isomitraphylline (2) in aqueous solution. Besides $\mathrm{pH}$ and solvent polarity, long-term heating processes can induce the isomerization of cat's claw alkaloids. ${ }^{4,12}$ Even a transient thermal effect seems to be critical in their isomerization, as observed after spray drying of cat's claw preparations. ${ }^{16}$

In this context, the aim of the present work was to evaluate the induction of isomerization of oxindole alkaloids by different extraction processes. The isomerization kinetics after heating under reflux were fitted by means of linear and non-linear mathematical models. Additionally, the equilibrium constants and isomerization rate coefficients for conversion of mitraphylline (1) to isomitraphylline (2) in the extraction and reference solutions after heating under reflux were compared.

\section{EXPERIMENTAL}

\section{Chemicals and reagents}

Acetonitrile HPLC grade (ACN) (Tedia, USA), ammonium acetate $\left(\mathrm{C}_{2} \mathrm{H}_{3} \mathrm{O}_{2} \mathrm{NH}_{4}\right)$ (Tedia, USA), ammonium hydroxide $\left(\mathrm{NH}_{4} \mathrm{OH}\right)$ (Merck, Germany) and ultrapure water obtained from a Milli-Q® system (Millipore, USA) were used in HPLC analysis. The mitraphylline (1) (Phytolab, batch 2946, Germany) and isomitraphylline (2) (Chromadex, batch 09417-101, USA) were used as external standards. The pteropodine (5) and isopteropodine (6), used only as identification standards, were isolated by preparative TLC in accordance with the previously proposed system ${ }^{17}$ and were characterized by HPLC-MS/MS analysis.

\section{Plant material}

An authentic sample of Uncaria tomentosa stem barks collected in Peru in May 2005, was kindly gifted by Quimer Ervas e Especiarias (São Paulo, batch 023, Brazil). The material was comminuted in a cutter mill (SK1 Retsch, Germany), equipped with a $2 \mathrm{~mm}$ steel sieve. 


\section{Pentacyclic oxindole alkaloids (POA)}

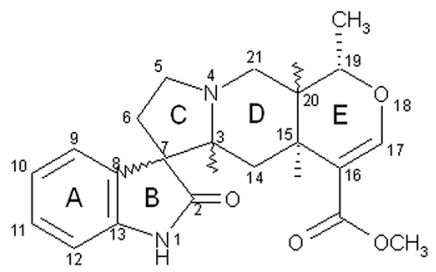

\begin{tabular}{|c|c|}
\hline Alkaloid & $\begin{array}{c}\text { Configuration } \\
(D / E \text { ring junction })\end{array}$ \\
\hline mitraphylline (1) & $\begin{array}{c}3 S, 7 R, 15 S, 19 S, 20 R \\
\text { (trans) }\end{array}$ \\
\hline isomitraphylline (2) & $\begin{array}{c}3 S, 7 S, 15 S, 19 S, 20 R \\
\text { (trans) }\end{array}$ \\
\hline speciophylline (3) & $\begin{array}{c}3 R, 7 S, 15 S, 19 S, 20 S \\
\text { (cis) }\end{array}$ \\
\hline uncarine F (4) & $\begin{array}{c}3 R, 7 R, 15 S, 19 S, 20 S \\
\text { (cis) }\end{array}$ \\
\hline pteropodine (5) & $\begin{array}{c}3 S, 7 R, 15 S, 19 S, 20 S \\
\text { (cis) }\end{array}$ \\
\hline isopteropodine (6) & $\begin{array}{c}3 S, 7 S, 15 S, 19 S, 20 S \\
\text { (cis) }\end{array}$ \\
\hline
\end{tabular}

Tetracyclic oxindole alkaloids (TOA)

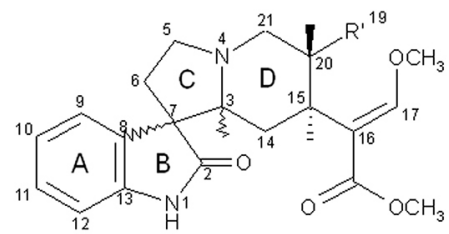

\begin{tabular}{cc}
\hline Alkaloid & $\begin{array}{c}\text { Configuration } \\
\text { (R') }\end{array}$ \\
\hline rhyncophylline (7) & $\begin{array}{c}3 S, 7 R, 15 S, 20 R \\
\text { (ethyl) }\end{array}$ \\
isorhyncophylline (8) & $\begin{array}{c}3 S, 7 S, 15 S, 20 R \\
\text { (ethyl) }\end{array}$ \\
corynoxeine (9) & $\begin{array}{c}3 S, 7 S, 15 S, 20 R \\
\text { (vinyl) }\end{array}$ \\
isocorynoxeine (10) & $3 S, 7 R, 15 S, 20 R$ \\
(vinyl)
\end{tabular}

Figure 1. Oxindole alkaloids isolated from Uncaria tomentosa bark ${ }^{l}$

The mean diameter $(223.11 \pm 7.03 \mu \mathrm{m})$ and moisture content $(7.92$ $\pm 0.21 \%$ ) of the powdered sample were determined by sieving and loss on drying, ${ }^{8}$ respectively.

\section{Extraction procedures}

All five extraction procedures were performed with a hydroethanolic solution $(40 \%, \mathrm{v} / \mathrm{v})$ at a drug:solvent ratio $(1: 10, \mathrm{w} / \mathrm{v})$ in line with a previous study. ${ }^{16}$ The extraction solutions were filtered through filter paper (Whatman, $n^{\circ} 2$ ). Filtrates were reconstituted to the initial volume with the same extraction solvent, properly diluted in $\mathrm{ACN}: \mathrm{H}_{2} \mathrm{O}(50: 50, \mathrm{v} / \mathrm{v})$, and filtered through a $0.45 \mu \mathrm{m}$ membrane (Millipore, USA) prior to analyses.

\section{Static maceration (SM)}

The extraction solution was obtained by four-day static maceration in an amber glass flask at room temperature $\left(23 \pm 1{ }^{\circ} \mathrm{C}\right)$ with occasional agitation (once a day).

\section{Dynamic maceration (DM)}

The extraction solution was obtained by 2 -h dynamic maceration in a magnetic stirring plate (RO 15 Power, IKA, Germany) at room temperature $\left(23 \pm 1^{\circ} \mathrm{C}\right)$, applying a stirring speed of $300 \mathrm{rpm}$ throughout the extraction process.

\section{Ultrasound-assisted extraction (UAE)}

The extraction solution was obtained by 45-min ultrasound (Ultra Cleaner 1400A, Unique, Brazil) at $40 \mathrm{kHz}$, in an amber glass flask at room temperature $\left(23 \pm 1{ }^{\circ} \mathrm{C}\right)$.

\section{Turbo-extraction (TE)}

The extraction solution was obtained at 11,000 rpm (Ultra-turrax T25 Basic, IKA, Germany). In order to avoid overheating, three processing cycles of 10-min each were interspersed with a 5-min pause per cycle.

\section{Reflux extraction ( $R E)$}

The extraction solution was obtained by 45 -min reflux in a system comprising an electrical isomantle (Fisatom, Brazil) as the heat source and a glass flask coupled to a condenser. The process time was started when the internal temperature reached $80{ }^{\circ} \mathrm{C}$, with the maximum temperature attained of $85 \pm 1^{\circ} \mathrm{C}$.

\section{HPLC analysis of oxindole alkaloids}

\section{HPLC-PDA analysis}

The reversed-phase gradient was performed employing an HPLC Proeminence device (Shimadzu, Tokyo, Japan) equipped with an FCV-10 AL system controller, an LC-20 AT pump system, a SIL-20 A automatic injector and an SPD-M20A detector. A Gemini-NX RP18 column $(250$ x $4.6 \mathrm{~mm}$ i.d., $5 \mu \mathrm{m})$ (Phenomenex, USA) protected by an RP-18 guard column ( 4.0 x $3.0 \mathrm{~mm}$ i.d.) was used. The mobile phase consisted of ammonium acetate buffer $10 \mathrm{mM}$ (adjusted to $\mathrm{pH}$ 7.0 with a solution of $\mathrm{NH}_{4} \mathrm{OH} 10 \%$ ) (solvent $\mathrm{A}$ ) and $\mathrm{ACN}$ (solvent B) in a linear gradient program: 34\% B (0-1 min); 34-40\% B (1-20 min); 40-43\% B (20-26 min); 43\% B (26-31 min); 43-34\% B (31-34 $\mathrm{min}$ ); and stop (38 min). The flow rate was kept constant at $1.0 \mathrm{~mL} /$ min and analyses were conducted at room temperature $\left(23 \pm 1{ }^{\circ} \mathrm{C}\right)$. The injection volume was $20 \mu \mathrm{L}$ with detection at $245 \mathrm{~nm}$. All data were processed by LC-Solution Multi-PDA software.

\section{HPLC-PDA validation}

The validation of the analytical method comprised specificity, linearity, limits of detection (LOD) and quantification (LOQ), repeatability, intermediary precision and accuracy tests according to the International Conference on Harmonization guidelines. ${ }^{18}$

\section{Specificity}

Specificity was evaluated through the peak purity index of the eight major peaks of the chromatograms, as well as by HPLC-MS/ MS analyses.

Linearity

The linearity tests comprised regression analysis. Stock reference 
solutions (20 $\mu \mathrm{g} / \mathrm{mL})$ of mitraphylline (1) and isomitraphylline (2) were prepared in methanol and then diluted in $\mathrm{ACN}: \mathrm{H}_{2} \mathrm{O}(50: 50, \mathrm{v} / \mathrm{v})$ to yield concentrations of $0.75 ; 1.5 ; 3.0 ; 4.5 ; 6.0$, and $7.5 \mu \mathrm{g} / \mathrm{mL}$. A 10 $\mathrm{mL}$ aliquot of DM extract was diluted accurately in $\mathrm{ACN}: \mathrm{H}_{2} \mathrm{O}(50: 50$, $\mathrm{v} / \mathrm{v}$ ) to yield concentrations of $0.21 ; 0.42 ; 0.64 ; 0.85$ and $1.06 \mathrm{mg} /$ $\mathrm{mL}$, expressed by the dry residue. The samples were filtered through a $0.45 \mu \mathrm{m}$ membrane prior to injection. Each analysis was repeated three times, over a three-day period.

\section{Limits of detection and quantification}

Limits of detection (LOD) and quantification (LOQ) were calculated based on the standard deviation of the regression analysis (SD) and the slope (S) of the mitraphylline (1) and isomitraphylline (2) curves. $^{18}$

\section{Intermediate precision and repeatability}

Repeatability was determined by RSD\% (relative standard deviation) from nine solutions of reference compounds $(4.5 \mu \mathrm{g} / \mathrm{mL})$ and DM extract $(0.64 \mathrm{mg} / \mathrm{mL})$ evaluated on the same day. Intermediate precision was determined by RSD\% from three solutions of reference solution $(4.5 \mu \mathrm{g} / \mathrm{mL})$ and $\mathrm{DM}$ extract $(0.64 \mathrm{mg} / \mathrm{mL})$ evaluated on three consecutive days.

\section{Accuracy}

Accuracy was evaluated by the recovery test after spiking known amounts of mitraphylline (1) and isomitraphylline (2) reference solutions in the DM extract at the three concentration levels of $50 \%$ $(0.75 \mu \mathrm{g} / \mathrm{mL}), 100 \%(1.5 \mu \mathrm{g} / \mathrm{mL})$ and $150 \%(3.0 \mu \mathrm{g} / \mathrm{mL})$ in relation to the amounts in DM extract.

\section{HPLC-MS/MS analysis}

Analyses were performed as described in HPLC-PDA analysis, using an HPLC 1200 series device (Agilent Technologies, Palo Alto, USA) coupled to a triple quadrupole API 5000 mass spectrometer (Applied Biosystems/Sciex, Foster City, USA). After chromatographic separation the analytes were introduced into the mass spectrometer through an electrospray probe operating in positive mode $\left(\mathrm{ESI}^{+}\right)$with a collision voltage of $5.5 \mathrm{kV}$. Nitrogen was used as the nebulizer (55 psi), curtain (15 psi), heater (55 psi) and collision (6 psi) gas. Heater temperature was set at $700{ }^{\circ} \mathrm{C}$. Data acquisition was performed in multiple reactions monitoring (MRM) mode and results processed by Analyst version 1.4.2 software (Applied Biosystems/ Sciex, Foster City, USA).

Aliquots of DM extract, isolated compounds (pteropodine (5) and isopteropodine (6)), and reference solutions (mitraphylline (1) and isomitraphylline (2)) were properly diluted to $25 \mathrm{ng} / \mathrm{mL}$ in ACN: $\mathrm{H}_{2} \mathrm{O}(50: 50, \mathrm{v} / \mathrm{v})$ and filtered through a $0.45 \mu \mathrm{m}$ membrane prior to analysis.

\section{Alkaloid isomerization analysis}

\section{Isomerization induced by drug extractions}

Alkaloid isomerization was monitored by quantifying each individual alkaloid content, expressed as percentage ratio in relation to total alkaloid concentrations of POA and TOA $\left(\left(\mathrm{C}_{\text {individual }} / \mathrm{C}_{\text {total }}\right)\right.$ $\times 100)$. The total concentrations of POA and TOA were obtained from the sum of individual alkaloid concentrations (1-6) and (7 and 8), respectively. Additionally, a mitraphylline (1):isomitraphylline (2) reference solution $(3: 1, \mathrm{w} / \mathrm{w})$ was prepared in hydroethanolic solution $(40 \%, v / v)$ reproducing the content ratio found in DM extract. This was submitted to the same conditions employed in the five extraction procedures (SM, DM, UAE, TE, RE) and analyzed before and after the procedures, thus acting as a control.
Effect of heating under reflux on composition of DM alkaloids

The DM extract was submitted to heating under reflux as described in reflux extraction and the product coded as DMR (dynamic maceration extract after heating under reflux). Each alkaloid content was quantified before and after processing. In addition, mitraphylline (1) and rhyncophylline (7) contents were compared to their interconvertible forms isomitraphylline (2) and isorhyncophylline (8), respectively. Likewise, the total sum of speciophylline (3), uncarine $\mathrm{F}(\mathbf{4})$, and pteropodine (5) contents was compared to that of isopteropodine $(\mathbf{6})$

\section{Statistical analysis}

The results were statistically evaluated by one-way ANOVA followed by Tukey's test and values of $p<0.01$ were considered significant.

\section{Kinetic analysis of alkaloid isomerization, determination of equilibrium constants $(K)$ and isomerization rate coefficients $\left(k_{i j}\right)$ during heating under reflux}

The DM extract and mitraphylline (1):isomitraphylline (2) reference solution $(3: 1, w / w)$ were submitted to heating under reflux. Aliquots were collected after 5; 10; 15; 30; 45; 60; 90; and $120 \mathrm{~min}$, properly diluted in $\mathrm{ACN}: \mathrm{H}_{2} \mathrm{O}(50: 50$, v/v) and filtered through a 0.45 $\mu \mathrm{m}$ membrane prior to analysis.

The kinetic of alkaloid isomerization was evaluated considering zero, first and second-order linear models. In addition, the MMF (Morgan-Mercer-Flodin) (Equation 1) and four-parameter Weibull (Equation 2) non-linear models were applied (Curve Expert 1.3 software).

$$
\begin{aligned}
& y=\frac{\left(a \times b+c \times x^{d}\right)}{\left(b+x^{d}\right)} \\
& y=a-b \times e^{\left(-c \times x^{d}\right)}
\end{aligned}
$$

The equilibrium was determined by the first derivative $(d y / d x)$ of the four-parameter Weibull equation (Equation 2) taking into account the same times used to determine isomerization kinetics. The equilibrium constants $(K)$ for conversion of mitraphylline (1) to isomitraphylline (2) in the DM extract and reference solution were determined before and after heating under reflux at time zero and at 45 min after reaction start. The isomerization rate coefficients $\left(k_{i j}\right)$ for the same conversion were determined by the following equations for homogeneous reversible reactions (Equation 3 and 4).

$$
\begin{aligned}
\ln \left([i]-[i]_{\infty}\right) & =\ln \left([i]_{\circ}-[i]_{\infty}\right)-\left(k_{i j}+k_{j i}\right) t \\
k_{j i} & =\frac{k_{i j}[i]_{\infty}}{\left([i]_{\circ}+[j]_{\circ}-[i]_{\infty}\right)}
\end{aligned}
$$

\section{RESULTS AND DISCUSSION}

\section{HPLC analysis of oxindole alkaloids}

\section{HPLC-PDA and HPLC-MS/MS analyses}

The HPLC-PDA method afforded the separation of six POAs (1-6) and two TOAs (7 and $\mathbf{8}$ ) with a suitable peak resolution (Figure $1 \mathrm{Sa}$, supplementary material). All compounds detected showed $\lambda_{\max }$ at 208-212 $\mathrm{nm}$ and $242-245 \mathrm{~nm}$, closely resembling typical oxindole alkaloids spectra. ${ }^{5}$ The identity of alkaloids (1-8) was established by HPLC-MS/MS analysis. All POAs produced a distinctive pseudomolecular ion $[\mathrm{M}+\mathrm{H}]^{+}$at $m / z, 369.3$, whilst the TOAs showed the 
ion at $m / z 385.4$ (Figure 1Se and 1Sf, supplementary material). The analysis of POA and TOA transitions at $m / z, 369.3 \rightarrow 337.1$, and $385.4 \rightarrow 353.4$, respectively (Figure $1 \mathrm{Sc}$ and $1 \mathrm{Sd}$, supplementary material), also allowed the recognition of each alkaloid class. ${ }^{19}$ The identity of mitraphylline (1), isomitraphylline (2), pteropodine (5), and isopteropodine (6) was confirmed through co-elution with reference substances. In addition, speciophylline (3), uncarine F (4), rhyncophylline (7), and isorhyncophylline (8) followed a similar elution order to that formerly reported by other authors. ${ }^{20-22}$ Neither corynoxeine (9) nor isocorynoxeine (10) were detectable by HPLC-PDA or HPLC-MS/ MS, probably due to their low content in cat's claw bark. ${ }^{19}$

\section{HPLC-PDA validation}

The HPLC-PDA method proved specific, linear, precise and accurate (Table $1 \mathrm{~S}$, supplementary material) in accordance with current ICH guidelines. ${ }^{18}$ Given that mitraphylline (1) is the most suitable oxindole alkaloid for assaying total alkaloid content in cat's claw bark, ${ }^{20}$ all content determinations were performed at 245 $\mathrm{nm}$ using mitraphylline (1) as the external standard. Exceptionally, isomitraphylline (2) was quantified as such, since it shows a very similar $\mathcal{E}$-value to mitraphylline $(\mathbf{1}){ }^{5,23}$

\section{Alkaloid isomerization analysis}

\section{Isomerization induced by drug extractions}

Comparatively, DM and UAE yielded intermediate alkaloid contents and very similar oxindole alkaloid profiles (Table 1). Moreover, the reference solution remained unchanged when processed in the same way. Owing to the lack of significant change, DM and UAE processes should be preferably chosen to avoid extraction-induced isomerization. In this sense, these results support the use of an ultrasound-assisted method for analytical purposes, as stated in the USP cat's claw monograph. ${ }^{8}$

DM was chosen for comparative purposes because it incorporated the main non-isomerized forms, namely, mitraphylline (1), speciophylline (3), pteropodine (5) and isorhyncophylline (8). In addition, the DM process did not significantly modify the reference solution (Table 1). Despite the higher contents of isopteropodine (6) and total POA obtained by TE in comparison to DM, high isomerization rates of mitraphylline (1), speciophylline (3) and isorhyncophylline (8) were also observed (Table 1). The alkaloid isomerization was likely induced by overheating, at least to some extent. Indeed, both high shear stress and hydrodynamic cavitation observed during turbo-extraction of fibrous plant material can overheat the system up to $70{ }^{\circ} \mathrm{C}$, even when a water cooling bath is used. ${ }^{16}$ Notably, an absence of isomerization was evidenced when the reference solution was processed under analogous conditions. The frictional energy generated by bark tissue processing in the TE seems to be responsible for the alkaloid isomerization.

Substantial isomerization was also observed after extraction of cat's claw bark by RE (Table 1), and similarly when the reference solution was processed in the same way. RE processing involves heating up to $85 \pm 3{ }^{\circ} \mathrm{C}$, typifying thermal-induced isomerization. This outcome agrees with the results of previous studies on the isomerization of isolated alkaloids, ${ }^{9,10}$ and also with another study that used a Soxhlet apparatus and methanol as the solvent. ${ }^{21}$ The susceptibility of speciophylline (3) to heating became evident by comparing HPLC-PDA profiles to those of the other processes shown in the present study, and is consistent with findings of former studies investigating speciophylline (3) isomerization in aqueous solution. ${ }^{4,6,9}$ Comparing RE processing to both DM and UAE revealed that its approximate four-fold content decrease was still lower than the six-fold decrease noted for extraction by boiling. ${ }^{4}$ Regarding the SM process, the extent of isomerization was less than for RE and probably associated with the long-term extraction (four days) employed.

\section{Effect of heating under reflux on composition of DM alkaloids}

The thermal effect on the composition of alkaloids was evaluated using a crude extract previously prepared by dynamic maceration (DM) and intentionally treated by heating under reflux, coded as DMR. The content of each alkaloid was determined again in DMR and compared to that of RE. As expected, DMR and RE total alkaloid contents (2.76 and $2.14 \mathrm{mg} / \mathrm{g}$, respectively) and the individual contents of POA and TOA differed (Table 2 - columns I and V). Nonetheless, the individual relative alkaloid content was statistically equivalent between them $(p>0.01)$ (Table 2 - columns II and VI). This indicates that both DMR and RE had similar alkaloid profiles.

Specifically with regard DMR, the increase in isomitraphylline (2) and rhyncophylline (7) was inversely correlated $(p>0.01)$ with decrease in their interconvertible alkaloids, mitraphylline (1) and isorhyncophylline (8), respectively (Table 2 - column VII). Despite the slight statistical difference $(p<0.01)$, for practical purposes the total content decrease of speciophylline (3), uncarine $F(4)$ and pteropodine (5) $(-0.50 \mathrm{mg} / \mathrm{g})$ was comparable to the increase of

Table 1. Oxindole alkaloid contents of cat's claw preparations obtained by different extraction processes

\begin{tabular}{|c|c|c|c|c|c|c|c|c|c|c|}
\hline \multirow{2}{*}{ Alkaloid } & \multicolumn{2}{|c|}{ DM } & \multicolumn{2}{|c|}{ UAE } & \multicolumn{2}{|c|}{ TE } & \multicolumn{2}{|c|}{ SM } & \multicolumn{2}{|c|}{$\mathrm{RE}$} \\
\hline & $\bar{X} \pm \mathrm{SD}^{1}$ & $\% \pm \mathrm{SD}^{2}$ & $\bar{X} \pm \mathrm{SD}^{1}$ & $\% \pm \mathrm{SD}^{2}$ & $\bar{X} \pm \mathrm{SD}^{1}$ & $\% \pm \mathrm{SD}^{2}$ & $\bar{X} \pm \mathrm{SD}^{1}$ & $\% \pm \mathrm{SD}^{2}$ & $\bar{X} \pm \mathrm{SD}^{1}$ & $\% \pm \mathrm{SD}^{2}$ \\
\hline mitraphylline (1) & $0.73 \pm 0.05$ & $29.67 \pm 0.14^{a}$ & $0.69 \pm 0.04$ & $28.91 \pm 2.20^{\mathrm{ac}}$ & $0.68 \pm 0.04$ & $25.29 \pm 1.65^{b}$ & $0.54 \pm 0.04$ & $27.37 \pm 0.13^{c}$ & $0.37 \pm 0.02$ & $19.66 \pm 1.65^{d}$ \\
\hline isomitraphylline (2) & $0.31 \pm 0.02$ & $12.36 \pm 0.04^{\mathrm{a}}$ & $0.28 \pm 0.02$ & $11.99 \pm 0.74^{a}$ & $0.43 \pm 0.05$ & $15.79 \pm 1.73^{b}$ & $0.26 \pm 0.02$ & $13.48 \pm 0.20^{c}$ & $0.41 \pm 0.06$ & $21.37 \pm 1.73^{\mathrm{d}}$ \\
\hline speciophylline (3) & $0.42 \pm 0.03$ & $16.88 \pm 0.30^{a}$ & $0.39 \pm 0.03$ & $16.25 \pm 1.25^{\mathrm{a}}$ & $0.26 \pm 0.06$ & $9.51 \pm 2.27^{b}$ & $0.26 \pm 0.02$ & $13.45 \pm 0.59^{c}$ & $0.12 \pm 0.01$ & $6.31 \pm 2.27^{\mathrm{d}}$ \\
\hline uncarine F (4) & $0.07 \pm 0.01$ & $2.94 \pm 0.03^{\mathrm{a}}$ & $0.07 \pm 0.01$ & $2.86 \pm 0.11^{\mathrm{a}}$ & $0.10 \pm 0.01$ & $3.58 \pm 0.13^{b}$ & $0.06 \pm 0.01$ & $3.16 \pm 0.06^{c}$ & $0.05 \pm 0.01$ & $2.38 \pm 0.13^{\mathrm{d}}$ \\
\hline pteropodine (5) & $0.69 \pm 0.04$ & $28.05 \pm 0.31^{\mathrm{a}}$ & $0.65 \pm 0.03$ & $27.25 \pm 1.17^{\mathrm{a}}$ & $0.74 \pm 0.04$ & $27.39 \pm 1.40^{\mathrm{a}}$ & $0.56 \pm 0.03$ & $28.39 \pm 0.26^{\mathrm{a}}$ & $0.34 \pm 0.05$ & $17.70 \pm 1.40^{\mathrm{b}}$ \\
\hline isopteropodine (6) & $0.25 \pm 0.01$ & $10.10 \pm 0.26^{\mathrm{a}}$ & $0.22 \pm 0.01$ & $9.17 \pm 0.14^{\mathrm{a}}$ & $0.50 \pm 0.10$ & $18.43 \pm 3.50^{b}$ & $0.28 \pm 0.02$ & $14.15 \pm 0.42^{c}$ & $0.62 \pm 0.08$ & $32.58 \pm 3.50^{d}$ \\
\hline Total $\mathrm{POA}^{3}$ & $2.47 \pm 0.14^{\mathrm{a}}$ & & $2.29 \pm 0.12^{\mathrm{a}}$ & & $2.70 \pm 0.03^{b}$ & & $1.97 \pm 0.13^{\mathrm{c}}$ & & $1.90 \pm 0.21^{\mathrm{c}}$ & \\
\hline rhyncophylline (7) & $0.19 \pm 0.01$ & $53.30 \pm 0.93^{a}$ & $0.16 \pm 0.01$ & $50.75 \pm 2.35^{a}$ & $0.20 \pm 0.01$ & $58.65 \pm 3.42^{b}$ & $0.14 \pm 0.01$ & $52.97 \pm 0.27^{a}$ & $0.17 \pm 0.02$ & $70.74 \pm 3.42^{c}$ \\
\hline isorhyncophylline (8) & $0.16 \pm 0.01$ & $46.70 \pm 0.93^{\mathrm{a}}$ & $0.15 \pm 0.01$ & $49.25 \pm 2.35^{\mathrm{a}}$ & $0.14 \pm 0.01$ & $41.35 \pm 3.42^{b}$ & $0.12 \pm 0.01$ & $47.03 \pm 0.27^{\mathrm{a}}$ & $0.07 \pm 0.01$ & $29.26 \pm 3.42^{\mathrm{c}}$ \\
\hline Total TOA ${ }^{4}$ & $0.35 \pm 0.02^{\mathrm{a}}$ & & $0.31 \pm 0.02^{b}$ & & $0.33 \pm 0.01$ ab & & $0.26 \pm 0.01^{\mathrm{c}}$ & & $0.24 \pm 0.02^{\mathrm{c}}$ & \\
\hline
\end{tabular}

\section{Reference solution ${ }^{5}$}

Before process

After process 
Table 2. Influence of heating under reflux on the oxindole alkaloid profile of dynamic maceration (DM) extract

\begin{tabular}{|c|c|c|c|c|c|c|c|}
\hline \multirow{2}{*}{ Alkaloid } & \multicolumn{2}{|c|}{$\mathrm{RE}$} & \multicolumn{2}{|c|}{$\mathrm{DM}$} & \multicolumn{2}{|c|}{ DMR } & \multirow{2}{*}{ 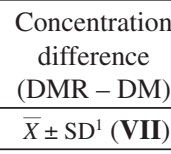 } \\
\hline & $\bar{X} \pm \mathrm{SD}^{1}(\mathbf{I})$ & $\% \pm \mathrm{SD}^{2}(\mathbf{I I})$ & $\bar{X} \pm \mathrm{SD}^{1}(\mathbf{I I I})$ & $\% \pm \mathrm{SD}^{2}(\mathbf{I V})$ & $\bar{X} \pm \mathrm{SD}^{1}(\mathbf{V})$ & $\% \pm \mathrm{SD}^{2}(\mathbf{V I})$ & \\
\hline mitraphylline (1) & $0.37 \pm 0.02$ & $19.66 \pm 1.65^{\mathrm{a}}$ & $0.70 \pm 0.03$ & $29.69 \pm 0.31^{b}$ & $0.50 \pm 0.01$ & $19.94 \pm 0.59^{\mathrm{a}}$ & $-0.21 \pm 0.02 * *$ \\
\hline isomitraphylline (2) & $0.41 \pm 0.06$ & $21.37 \pm 1.73^{\mathrm{a}}$ & $0.26 \pm 0.01$ & $10.92 \pm 0.42^{b}$ & $0.49 \pm 0.03$ & $19.72 \pm 0.45^{\mathrm{a}}$ & $0.23 \pm 0.02 * *$ \\
\hline speciophylline (3) & $0.12 \pm 0.01$ & $6.31 \pm 2.27^{\mathrm{a}}$ & $0.40 \pm 0.02$ & $16.83 \pm 0.21^{b}$ & $0.14 \pm 0.01$ & $5.66 \pm 0.37^{\mathrm{a}}$ & $-0.26 \pm 0.02$ \\
\hline uncarine F (4) & $0.05 \pm 0.01$ & $2.38 \pm 0.13^{a}$ & $0.07 \pm 0.01$ & $2.90 \pm 0.07^{\mathrm{b}}$ & $0.06 \pm 0.01$ & $2.45 \pm 0.08^{\mathrm{a}}$ & $-0.01 \pm 0.01$ \\
\hline pteropodine (5) & $0.34 \pm 0.05$ & $17.70 \pm 1.40^{a}$ & $0.71 \pm 0.03$ & $30.09 \pm 0.53^{b}$ & $0.48 \pm 0.03$ & $19.32 \pm 0.86^{\mathrm{a}}$ & $-0.23 \pm 0.01$ \\
\hline isopteropodine (6) & $0.62 \pm 0.08$ & $32.58 \pm 3.50^{a}$ & $0.23 \pm 0.01$ & $9.57 \pm 0.56^{\mathrm{b}}$ & $0.81 \pm 0.05$ & $32.91 \pm 1.13^{a}$ & $0.58 \pm 0.04$ \\
\hline Total $\mathrm{POA}^{3}$ & $1.90 \pm 0.21^{a}$ & & $2.37 \pm 0.08^{b}$ & & $2.47 \pm 0.09^{\mathrm{c}}$ & & \\
\hline rhyncophylline (7) & $0.17 \pm 0.01$ & $70.74 \pm 3.42^{\mathrm{a}}$ & $0.16 \pm 0.01$ & $55.13 \pm 0.54^{b}$ & $0.21 \pm 0.01$ & $73.00 \pm 0.67^{\mathrm{a}}$ & $0.05 \pm 0.01 * *$ \\
\hline isorhyncophylline (8) & $0.07 \pm 0.01$ & $29.26 \pm 3.42^{\mathrm{a}}$ & $0.13 \pm 0.01$ & $44.87 \pm 0.54^{b}$ & $0.08 \pm 0.01$ & $27.00 \pm 0.67^{a}$ & $-0.05 \pm 0.01 * *$ \\
\hline Total TOA ${ }^{4}$ & $0.24 \pm 0.02^{a}$ & & $0.30 \pm 0.01^{\mathrm{b}}$ & & $0.29 \pm 0.01^{\mathrm{b}}$ & & \\
\hline
\end{tabular}

a,b,csame letters indicate an individual alkaloid relative content statistically equivalents by Tukey's test $(p>0.01)$; ${ }^{1}$ expressed in $\mathrm{mg} / \mathrm{g}$ of dry material by mean \pm standard deviation $(\bar{X} \pm \mathrm{SD}, \mathrm{n}=3) ;{ }^{2}$ expressed in $\left(\mathrm{C}_{\text {individual }} / \mathrm{C}_{\text {total }}\right) \times 100$ by mean \pm standard deviation $(\% \pm \mathrm{SD}, \mathrm{n}=3) ;{ }^{3}$ sum of $(\mathbf{1}-\mathbf{6})$ concentrations; ${ }^{4}$ sum of (7) and (8) concentrations; **increases of (2) and (7) were equivalent to decreases of (1) and (8), respectively $(p>0.01)$. Dynamic maceration (DM), reflux extraction (RE), and dynamic maceration extract after heating under reflux (DMR).

isopteropodine (6) $(0.58 \mathrm{mg} / \mathrm{g})$ (Table 2 - column VII). Any potential interference in the HPLC-PDA analyses from other substances having the same retention time as oxindole alkaloids was ruled out by monitoring the peak purity index. Thus, the thermal effect should be solely responsible for the distinct alkaloid profile present in RE extract induced by isomerization.

Kinetic analysis of alkaloid isomerization and determination of equilibrium constants $(K)$ and isomerization rate coefficients $\left(k_{i j}\right)$ after heating under reflux

Decoction is, by far, the most commonly used extraction method

(a)

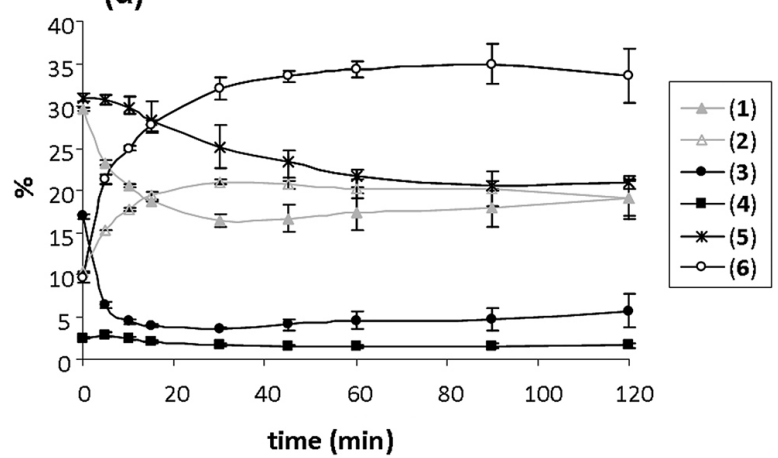

(b)

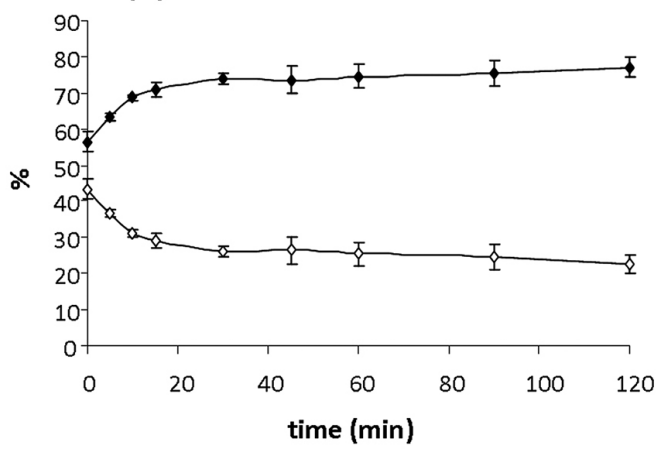

in ethnopharmacological and biological studies concerning cat's claw bark. ${ }^{6}$ In the present study, a reflux device coupled to the extraction vessel was used to avoid solvent loss. The kinetic curves after heating under reflux of DM extract are shown in Figure 2.

The best curve fit of kinetic data was attained by applying mathematical non-linear models, namely, the four-parameter Weibull and MMF, instead of zero, first and second-order linear models, as indicated by comparing the individual values of $\mathrm{R}^{2}$ and $\mathrm{S}$ (Table $2 \mathrm{~S}$, supplementary material). The only exception was uncarine $\mathrm{F}$ (4) because of its low content in the extract. Finally, the four-parameter Weibull model (Table 3S, supplementary material) allowed a still

(c)

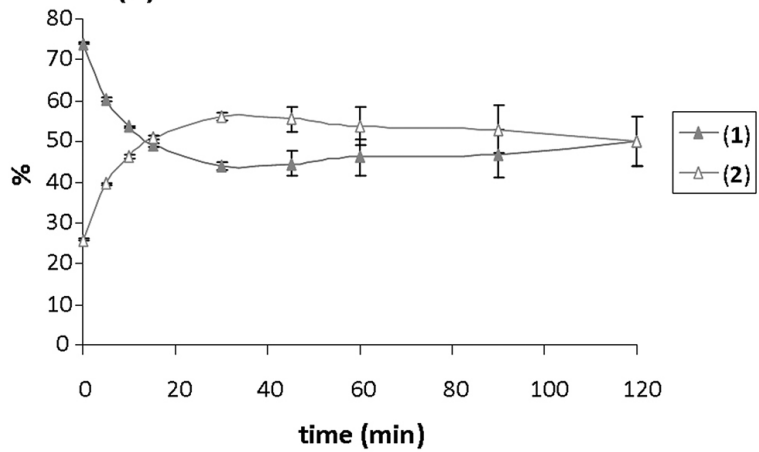

(d)

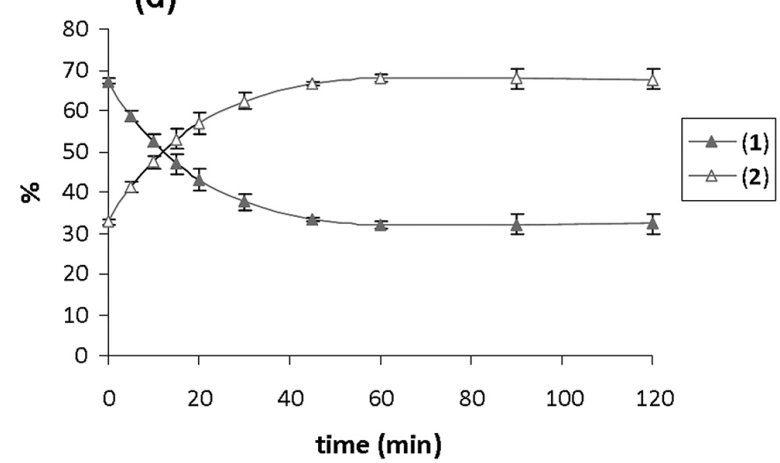

Figure 2. HPLC-PDA monitoring of alkaloid isomerization after heating under reflux of pentacyclic oxindole alkaloid (POA) (a) and tetracyclic oxindole alkaloids (TOA) (b) in dynamic maceration (DM) extract; Comparison of interconversion between mitraphylline (1) and isomitraphylline (2) in DM extract (c) and reference solution (d); Black line and gray line for POA with cis and trans D/E ring junction, respectively. Mitraphylline (1), isomitraphylline (2), speciophylline (3), uncarine F (4), pteropodine (5), isopteropodine (6) rhyncophylline (7), and isorhyncophylline (8) 
better data fit than the MMF model and all additional analyses were therefore done taking this into account.

Based on the kinetic data, it can be concluded that heating under reflux of DM was able to displace the equilibrium toward the conversion of mitraphylline (1) to isomitraphylline (2) (Figure 2a), as well as toward the conversion of isorhyncophylline (8) to rhyncophylline (7) (Figure $2 b$ ). As previously proposed, the interconversions of POA with trans $\mathrm{D} / \mathrm{E}$ ring junction and TOA should be endothermic reactions, ${ }^{9,10}$ and according to the free energy Gibbs equation, this implies a positive entropy variation and explains why isomerization was hindered at low temperature, as applied in the DM process $\left(23 \pm 1^{\circ} \mathrm{C}\right)$ and, conversely, why it was induced by higher temperatures, as observed in the RE process $\left(85 \pm 1^{\circ} \mathrm{C}\right)$. Likewise, the conversion of speciophylline $(\mathbf{3})$, uncarine $\mathrm{F}(\mathbf{4})$, and pteropodine (5) to isopteropodine (6) (POA with cis $\mathrm{D} / \mathrm{E}$ ring junction) also seems to be endothermic.

After 45-min of heating under reflux, the isomerization rate achieved a new equilibrium for all alkaloids considered here. At this timepoint, the first derivative $(d y / d x)$ of data fitted by the four-parameter Weibull model remained practically constant in all cases (Figure 3). The highest initial isomerization rate regarding POA with cis D/E ring junction was ascribed to isopteropodine (6). Pteropodine (5) also showed a higher lag time compared to speciophylline (3) (Figure 3a). This indicates that, in early stages of heating under reflux, isopteropodine (6) was formed predominantly from speciophylline (3) while conversion from pteropodine (5) occurred only later. Regarding the interconvertible POA with trans $\mathrm{D} / \mathrm{E}$ ring junction, the initial isomerization rate was higher toward the formation of isomitraphylline (2) than in the opposite direction (Figure 3b). Concerning TOA interconversion, the equilibrium was displaced toward rhyncophylline (7) formation, as indicated by its initial isomerization rate (Figure $3 \mathrm{c}$ ).

It is noteworthy that the equilibrium constant $(K)$ as well as both isomerization rate constants $\left(k_{12}, k_{21}\right)$ of mitraphylline (1) and isomitraphylline (2), calculated for the DM extract after heat refluxing, differed significantly to those of the reference solution treated under analogous conditions (Figure $2 \mathrm{c}, 2 \mathrm{~d}$ and Table 3 ).

It is highly likely that both reaction equilibrium and isomerization rate differences were produced by other extract components as a result of the stabilization of the zwitterionic intermediate and formation of intramolecular hydrogen bonds, respectively, as previously proposed. ${ }^{9}$ Specifically, zwitterionic intermediate stabilization can be induced by polyphenols and quinovic acid glycosides present in the extraction solution. ${ }^{1,24}$ Thus, the isomerization rate in DM was higher than in the reference solution. In addition, the acid $\mathrm{pH}$ of the DM extract $(\mathrm{pH} 5.25 \pm 0.02)$ might lead to protonation at N-4 with consequent formation of an intramolecular hydrogen bond between protonated $\mathrm{N}-4$ and lactam carbonyl in the syn position. Therefore, the conversion of mitraphylline (1) to isomitraphylline (2) was hindered in DM for the most part, but not in the reference solution.

\section{CONCLUSIONS}

The results obtained revealed that the extent of alkaloid isomerization differed among the extraction processes evaluated. By far, the highest alkaloid isomerization was observed in reflux extraction followed by turbo-extraction and long-term static maceration. Conversely, short-term processes using lower temperature, such as dynamic maceration and ultrasound-assisted extraction, seemed to prevent alkaloid isomerization. Despite the complexity of alkaloid interconversion, the kinetic curves after heating under reflux of oxindole alkaloids could be adjusted to fit a four-parameter Weibull model. Comparison with a reference solution composed of mitraphylline (1) and isomitraphylline (2) strongly suggests that oxindole alkaloids in cat's claw extracts might behave differently to when they are assayed as isolated compounds. This finding may demonstrate how the isomerization of individual alkaloids really occurs in cat's claw extract. Finally, it became clear that the biological activities of
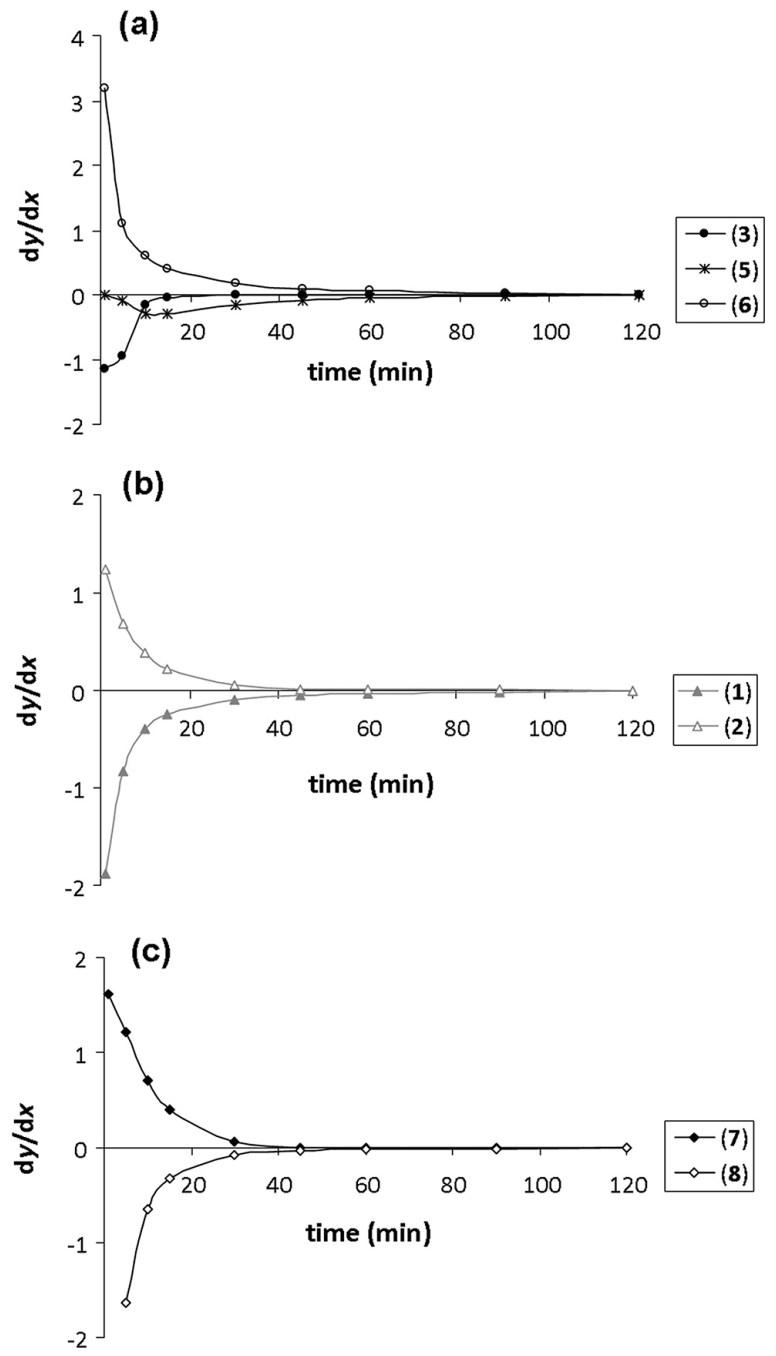

Figure 3. The first derivative ( $d x / d y)$ from the data fitted by Weibull equation in function of reaction time of pentacyclic oxindole alkaloid (POA) having cis $D / E(\boldsymbol{a})$ and trans $D / E$ ring junctions $(\boldsymbol{b})$, and tetracyclic oxindole alkaloids (TOA) (c). Mitraphylline (1), isomitraphylline (2), speciophylline (3), pteropodine (5), isopteropodine (6), rhyncophylline (7), and isorhyncophylline (8)

Table 3. Equilibrium constants $(K)$ and isomerization rate coefficients $\left(k_{i j}\right)$ for conversion of mitraphylline (1) to isomitraphylline (2) in the dynamic maceration (DM) extract and reference solution

\begin{tabular}{ccc}
\hline & $K$ & \\
Sample & Before heating under reflux & $k_{12}{ }^{\mathrm{a}}$ \\
& $\begin{array}{c}{ }^{\mathrm{a}} \\
\text { After heating under reflux } \\
\mathrm{CI}(\alpha=0.05)\end{array}$ & $\mathrm{CI}(\alpha=0.05)$ \\
\hline \multirow{2}{*}{ DM extract } & 0.348 & 0.0514 \\
& $(0.344 ; 0.353)$ & $(0.0425 ; 0.0603)$ \\
& 1.152 & 0.0321 \\
Reference solution & $(1.037 ; 1.268)$ & $(0.0265 ; 0.0373)$ \\
\hline & $(0.458 ; 0.514)$ & 0.0463 \\
& 2.082 & $0.0398 ; 0.0528)$ \\
& $(1.994 ; 2.171)$ & $(0.0200 ; 0.0265)$ \\
\hline
\end{tabular}

Confidence interval range $(\mathrm{CI}) ;{ }^{\mathrm{a}}(\% / \mathrm{min})$. 
cat's claw can depend on the particular extraction process applied to obtain the intermediary or final product.

\section{SUPPLEMENTARY MATERIAL}

Available at http://quimicanova.sbq.org.br, as a PDF file, with free access. The HPLC-PDA and HPLC-MS/MS profiles of oxindole alkaloids in extraction solution obtained from dynamic maceration are shown in Figure 1S. HPLC-PDA validation parameters are shown in Table 1S. The regression parameters after fitting of kinetics data through linear and non-linear models are shown in Table $2 \mathrm{~S}$. The four-parameter Weibull model for kinetic curves of oxindole alkaloids after heating under reflux are shown in Table $3 \mathrm{~S}$.

\section{ACKNOWLEDGMENTS}

The authors are grateful to the Conselho Nacional de Desenvolvimento Científico e Tecnológico (CNPq) and Coordenação de Aperfeiçoamento de Pessoal de Nível Superior (CAPES) for financial support and to the Centro de DesenvolvimentoTecnológico Farmacêutico (CDTF/UFRGS) and Laboratório Nacional Agropecuário (LANAGRO-RS) for technical support.

\section{REFERENCES}

1. Heitzman, M. E.; Neto, C. C.; Winiarz, E.; Vaisberg, A. J.; Hammond, G. B.; Phytochemistry 2005, 66, 5.

2. Reinhard, K. H.; J. Altern. Complem. Med. 1999, 5, 143.

3. Bacher, N.; Tiefenthaler, M.; Sturm, S.; Stuppner, H.; Ausserlechner, M. J.; Kofler, R.; Konwalinka, G.; Brit. J. Haematology 2006, 132, 615.

4. Pilarski, R.; Filip, B.; Wietrzyk, J.; Kura's, M.; Gulewicz, K.; Phytomed. 2010, 17, 1133.

5. Wagner, H.; Kreutzkamp, B.; Jurcic, K.; Planta Med. 1985, 51, 419.

6. Keplinger, K.; Laus, G.; Wurm, M.; Dierich, M. P.; Teppner, H.; J. Ethnopharmacol. 1999, 64, 23.

7. Hemingway, S. R.; Phillipson, J. D.; J. Pharm. Pharmacol. 1974, 26, 113; Laus, G.; Brössner, D.; Keplinger, K.; Phytochemistry 1997, 45, 855; Lemaire; I.; Assinewe, V.; Cano, P.; Awang, D. V. C.; Arnason, J. T.; J. Ethnopharmacol. 1999, 64, 109; Reis, S. R. I. N.; Valente, L. M.
M.; Sampaio, A. L.; Siani, A. C.; Gandini, M.; Azeredo, E. L.; Mazzei, J. L.; D'avila, L. A.; Kubelka, C. F.; Henriques, M. G. M.; Int. Immunopharmacol. 2008, 8, 468 .

8. United States Pharmacopeia: First supplement, $36^{\text {th }}$ ed., U.S. Pharmacopeia: Rockville, 2013.

9. Laus, G.; Brössner, D.; Senn, G.; Wurst, K.; J. Chem. Soc. Perkin. Trans. 2 1996, 1931

10. Laus, G.; J. Chem. Soc. Perkin. Trans. 2 1998, 315.

11. Lima, V. L. E.; Quim. Nova 1997, 20, 657.

12. Pilarski, R.; Poczekaj-Kostrzewska, M.; Ciesiolka, D.; Szyfter, K.; Gulewicz, K.; Pharmacol. Rep. 2007, 59, 565.

13. Muhammad, I.; Dunbar, D. C.; Khan, R. A.; Ganzera, M.; Khan, I. A.; Phytochemistry 2001, 57, 781 .

14. Prado, G. E.; Giménez, G. M. D.; Vázquez, D. R.; Sánchez, E. J. L.; Rodríguez, S. M. T.; Phytomed. 2007, 4, 280.

15. Giménez, D. G.; Prado, E. G.; Rodríguez, T. S.; Arche, A. F.; De la Puerta R.; Planta Med. 2010, 76, 133.

16. Pavei, C.; Borré, G. L.; Kaiser, S.; Ortega, G. G.; Lat. Am. J. Pharm. 2011, 30, 608.

17. Valente, L. M. M.; Alves, F. F.; Bezerra, G. M.; Almeida, M. B. S.; Rosario, S. L.; Mazzei, J. L.; D'avila, L. A.; Siani, A. C.; Braz. J. Pharmacogn. 2006, 16, 216.

18. Validation of Analytical Procedures: Text and Methodology, ICH Guidelines, Q2 (R1), International Conference on Harmonisation: Geneva, 2005.

19. Montoro, P.; Carbone, V.; Quiroz, J. D. Z.; De Simone, F.; Pizza, C.; Phytochem. Anal. 2004, 15, 55.

20. Bertol, G.; Franco, L.; Oliveira, B. H.; Phytochem. Anal. 2012, 23, 143.

21. Laus, G.; Keplinger, D.; J. Chromatogr. A 1994, 662, 243.

22. Aguilar, J. L.; Rojas, P.; Marcelo, A.; Plaza, A.; Bauer, R.; Reininger, E.; Klaas, C. A.; Merfort, I.; J. Ethnopharmacol. 2002, 81, 271; Ganzera, M.; Muhammad, I.; Khan, R. A.; Khan, I. A.; Planta Med. 2001, 67, 447.

23. Stuppner, H.; Sturm, S.; Konwalinka, G.; Chromatographia 1992, 34, 597.

24. Pavei, C.; Kaiser, S.; Borré, G. L.; Ortega, G. G.; J. Liq. Chromatogr. Relat. Technol. 2010, 33, 1551; Pavei, C.; Kaiser, S.; Verza, S. G.; Borré, G. L.; Ortega, G. G.; J. Pharm. Biomed. Anal. 2012, 62, 250. 


\section{CAT'S CLAW OXINDOLE ALKALOID ISOMERIZATION INDUCED BY COMMON EXTRACTION METHODS}

Samuel Kaiser*, Simone Gasparin Verza, Renata Cougo Moraes, Pedro Ernesto de Resende, Cabral Pavei, George González Ortega

Faculdade de Farmácia, Universidade Federal do Rio Grande do Sul, 90610-000 Porto Alegre - RS, Brasil

Fabiano Barreto

Laboratório Nacional Agropecuário, 91780-580 Porto Alegre - RS, Brasil

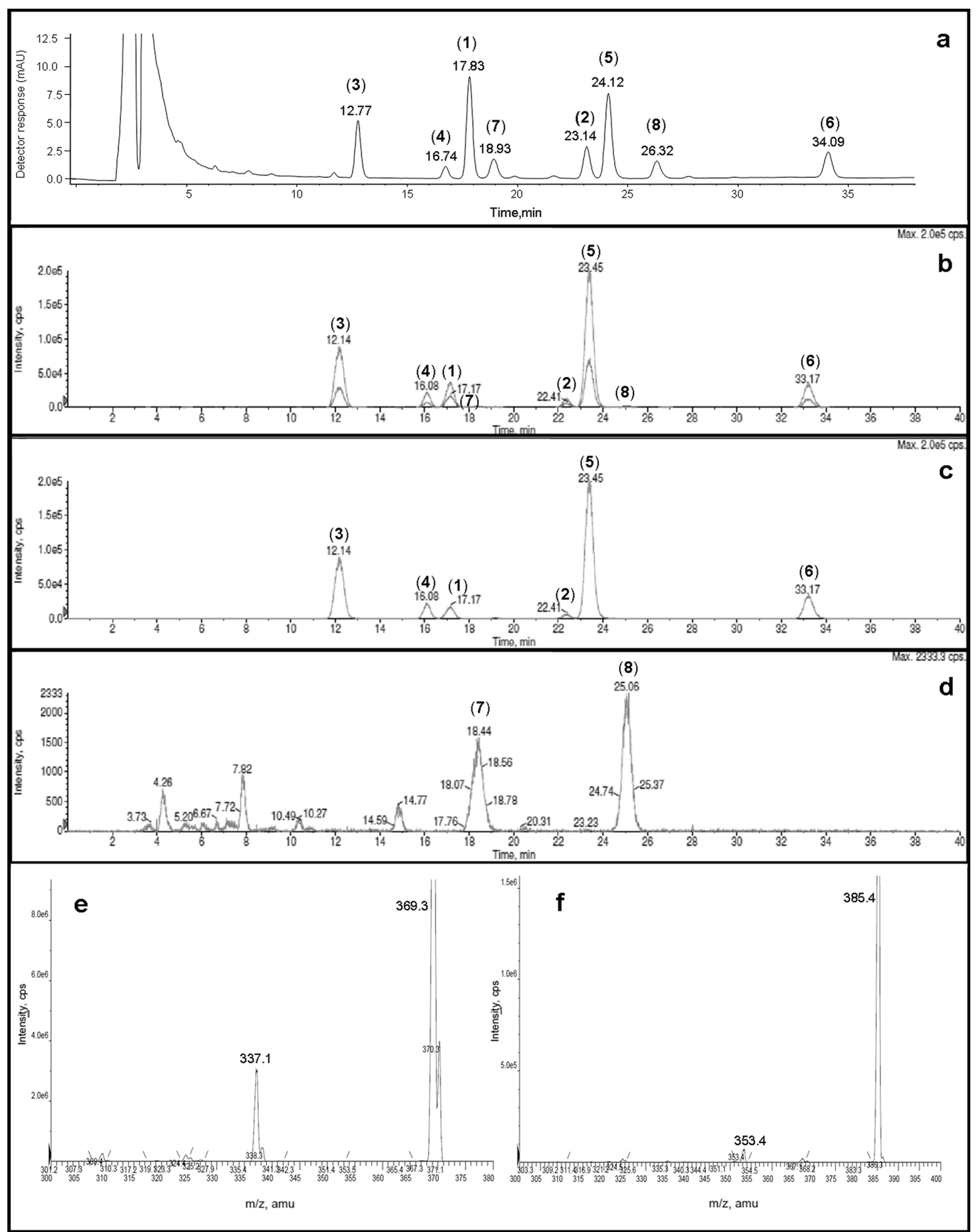

Figure 1S. HPLC-PDA profile of oxindole alkaloids in DM extract, at $245 \mathrm{~nm}(\mathrm{a}) ; H P L C-M S / M S$ profiles monitoring the pseudomolecular ions [M+H] $]^{+}$at $\mathrm{m} / \mathrm{z} 369.3$ for pentacyclic oxindole alkaloid (POA), and m/z 385.4 for tetracyclic oxindole alkaloids (TOA) (b); Distinctive transitions of POA at m/z $369.3 \rightarrow$ $337.1(\boldsymbol{c})$, and TOA at $\mathrm{m} / \mathrm{z} 385.4 \rightarrow 353.4(\boldsymbol{d}) ; \mathrm{MS} / \mathrm{MS}$ spectra of POA $(\boldsymbol{e})$, and TOA $(\boldsymbol{f})$. Mitraphylline $(\mathbf{1})$, isomitraphylline (2), speciophylline (3), uncarine F (4), pteropodine (5), isopteropodine (6), rhyncophylline (7), and isorhyncophylline (8)

*e-mail: samokaiser@yahoo.com.br 
Table 1S. HPLC-PDA validation parameters concerning to individual alkaloid contents in dynamic maceration (DM) extract of cat's claw bark

\begin{tabular}{|c|c|c|c|c|c|c|c|c|}
\hline \multirow{2}{*}{ Parameters } & \multicolumn{6}{|c|}{ Pentacyclic oxindole alkaloid (POA) } & \multicolumn{2}{|c|}{$\begin{array}{c}\text { Tetracyclic oxindole alkaloids } \\
\text { (TOA) }\end{array}$} \\
\hline & $\begin{array}{l}\text { mitraphylline } \\
\text { (1) }\end{array}$ & $\begin{array}{l}\text { isomitraphylline } \\
\text { (2) }\end{array}$ & speciophylline (3) & $\begin{array}{l}\text { uncarine } \mathrm{F} \\
\mathbf{( 4 )}\end{array}$ & $\begin{array}{c}\text { pteropodine } \\
(\mathbf{5})\end{array}$ & $\begin{array}{l}\text { isopteropodine } \\
(\mathbf{6})\end{array}$ & $\begin{array}{l}\text { rhyncophylline } \\
\text { (7) }\end{array}$ & $\begin{array}{c}\text { isorhyncophylline } \\
(\mathbf{8})\end{array}$ \\
\hline \multicolumn{9}{|l|}{ Peak purity index } \\
\hline Extractive solution & 0.9999 & 0.9999 & 0.9999 & 0.9999 & 0.9999 & 0.9999 & 0.9999 & 0.9999 \\
\hline Reference compound & 0.9999 & 0.9999 & - & - & 0.9999 & 0.9999 & - & - \\
\hline \multicolumn{9}{|l|}{$\overline{\mathbf{R}^{2}}$} \\
\hline Extractive solution & 0.9994 & 0.9988 & 0.9989 & 0.9984 & 0.9993 & 0.9987 & 0.9989 & 0.9988 \\
\hline Reference compound & 0.9995 & 0.9994 & - & - & - & - & - & - \\
\hline \multicolumn{9}{|l|}{ Regression equation } \\
\hline Extractive solution & $y=55784 x-658$ & $y=20675 x-1336$ & $y=31011 x+1835$ & $y=5475.2 x-658$ & $y=53253 x-3785$ & $y=20802 x-5131$ & $y=13333 x-917$ & $y=12412 x-1566$ \\
\hline Reference compound & $y=35492 x-745$ & $y=33708 x-1766$ & - & - & - & - & - & - \\
\hline \multicolumn{9}{|c|}{ LOD $(\mu \mathrm{g} / \mathrm{mL}) ; \mathrm{LOQ}(\mu \mathrm{g} / \mathrm{mL})$} \\
\hline Reference compound & $0.08 ; 0.24$ & $0.09 ; 0.27$ & - & - & - & - & - & - \\
\hline \multicolumn{9}{|l|}{ Repeatability (RSD \%) } \\
\hline Extractive solution & 0.15 & 0.94 & 0.51 & 1.53 & 0.58 & 1.01 & 2.96 & 0.93 \\
\hline Reference compound & 0.70 & 0.20 & - & - & - & - & - & - \\
\hline \multicolumn{9}{|c|}{ Intermediate precision (RSD \%) } \\
\hline Extractive solution & 1.13 & 4.48 & 0.89 & 2.80 & 0.97 & 1.40 & 3.28 & 1.82 \\
\hline Reference compound & 2.40 & 0.70 & - & - & - & - & - & - \\
\hline $\begin{array}{l}\text { Recovery \% }(\bar{X} \pm \mathbf{S D}) \\
\text { Reference compound }\end{array}$ & $101.0 \pm 0.5$ & $101.9 \pm 1.8$ & - & - & - & - & - & - \\
\hline
\end{tabular}

Coefficient of determination $\left(\mathrm{R}^{2}\right)$; Limit of detection (LOD) and quantification (LOQ); Relative standard deviation (RSD\%); mean \pm standard deviation $(\bar{X} \pm$ SD).

Table 2S. Coefficients of determination $\left(\mathrm{R}^{2}\right)$ and regression variance $(\mathrm{S})$ after fitting of kinetic data through linear and non-linear models

\begin{tabular}{lcc}
\hline Alkaloid & \multicolumn{2}{c}{ Models: zero-order; first-order; second-order; Weibull; MMF } \\
\hline mitraphylline (1) & $\mathrm{R}^{2}$ & $\mathrm{~S}$ \\
isomitraphylline (2) & $0.661 ; 0.717 ; 0.761 ; 0.999 ; 0.999$ & $2.77 ; 0.05 ; 0.01 ; 0.16 ; 0.13$ \\
speciophylline (3) & $0.650 ; 0.584 ; 0.516 ; 0.999 ; 0.999$ & $2.30 ; 0.07 ; 0.01 ; 0.07 ; 0.17$ \\
uncarine F (4) & $0.360 ; 0.435 ; 0.500 ; 0.999 ; 0.999$ & $3.96 ; 0.18 ; 0.06 ; 0.05 ; 0.05$ \\
pteropodine (5) & $0.730 ; 0.790 ; 0.823 ; \mathrm{ND} ; \mathrm{ND}$ & $0.28 ; 0.49 ; 0.05 ; \mathrm{ND} ; \mathrm{ND}$ \\
isopteropodine (6) & $0.809 ; 0.798 ; 0.782 ; 0.999 ; 0.999$ & $1.46 ; 0.02 ; 0.01 ; 0.04 ; 0.16$ \\
rhyncophylline (7) & $0.720 ; 0.569 ; 0.443 ; 0.999 ; 0.999$ & $4.47 ; 0.13 ; 0.02 ; 0.32 ; 0.37$ \\
isorhyncophylline $(\mathbf{8})$ & $0.589 ; 0.564 ; 0.537 ; 0.999 ; 0.999$ & $4.54 ; 0.03 ; 0.01 ; 0.36 ; 0.23$ \\
\hline
\end{tabular}

Not determined (ND).

Table 3S. Fitted values of the four-parameter Weibull model for kinetic curves of oxindole alkaloids on dynamic maceration (DM) extract after heating under reflux

\begin{tabular}{ccccc}
\hline Alkaloid & \multicolumn{3}{c}{ Parameter } & $\mathrm{c}$ \\
\cline { 2 - 5 } & $\mathrm{a}$ & $\mathrm{b}$ & 2.84 & -0.57 \\
\hline mitraphylline (1) & 29.68 & 19.78 & 0.13 & 0.92 \\
isomitraphylline (2) & 21.45 & 11.29 & 4.56 & -1.81 \\
speciophylline (3) & 16.91 & 13.42 & 26.70 & -1.06 \\
pteropodine (5) & 30.94 & 12.07 & 0.24 & 0.57 \\
isopteropodine (6) & 37.14 & 29.35 & 0.09 & 1.10 \\
rhyncophylline (7) & 74.18 & 17.81 & 6.51 & -1.15 \\
isorhyncophylline (8) & 43.47 & 19.32 & & \\
\hline
\end{tabular}

